\title{
Flint quarrying in north-eastern Iberia: quarry sites and the initial transformation of raw material
}

Xavier Terradas \& David Ortega*

\section{Introduction}

Prehistoric communities carried out quarrying activities to obtain raw materials for tool production. These were produced either directly for immediate or later use by the same groups who quarried the stone, or indirectly by distributing the raw material or partially or completely manufactured products to third parties. All these procedures could be performed within a temporal and spatial sequence of variable extent, giving rise to archaeological evidence of very different types (Nelson 1991; Ingold 2012).

Archaeological sites related to stone quarrying have not always received the scientific attention they deserve, probably due to poor preservation and the difficulty in their identification. It was not until the Neolithic period (c. fifth millennium BC) that the increased demand for flint for the production of blades and axes intensified the quarrying activities that left identifiable traces in the landscape (Figure 1) (Binder \& Perlès 1990).

\section{Quarry sites and the initial transformation of lithic raw material}

Quarrying activities took place on the rock outcrops, resulting in anthropic modification of their natural arrangement, as well as introducing non-local elements to the site in the form of mining tools (Figure 2). The more intensive and recurrent these quarrying activities were, the more evident their effects, thus enabling their archaeological identification. Particular archaeological features were formed, linked to the extraction of the raw material and its initial transformation (Ericson \& Purdy 1984).

Studying these archaeological deposits can provide important data about fundamental aspects of the first stages in the production processes, as their design is indicative of planning in the community's production system. These involve the following (Terradas 2001):

- The initial phases in the lithic tools manufacturing sequence, in which the raw material was shaped for the production of tool blanks and its transportation to other sites.

Spanish National Research Council (CSIC_IMF), Archaeology of Social Dynamics, Carrer de les Egipciaques 15, 08001 Barcelona, Spain

Author for correspondence (Email: terradas@imf.csic.es) 
- The patterns followed in the choice and rejection of raw material, from the points of view of its lithology and of its properties and morphological characteristics.

- The technical skills involved in these processes so as to establish models of optimal efficiency in the procurement and use of raw material.

\section{Preliminary results}

In recent years, a number of thematic surveys have been carried out with the goal of creating a lithotheque (or 'rock library') addressing the availability of siliceous rocks in north-eastern

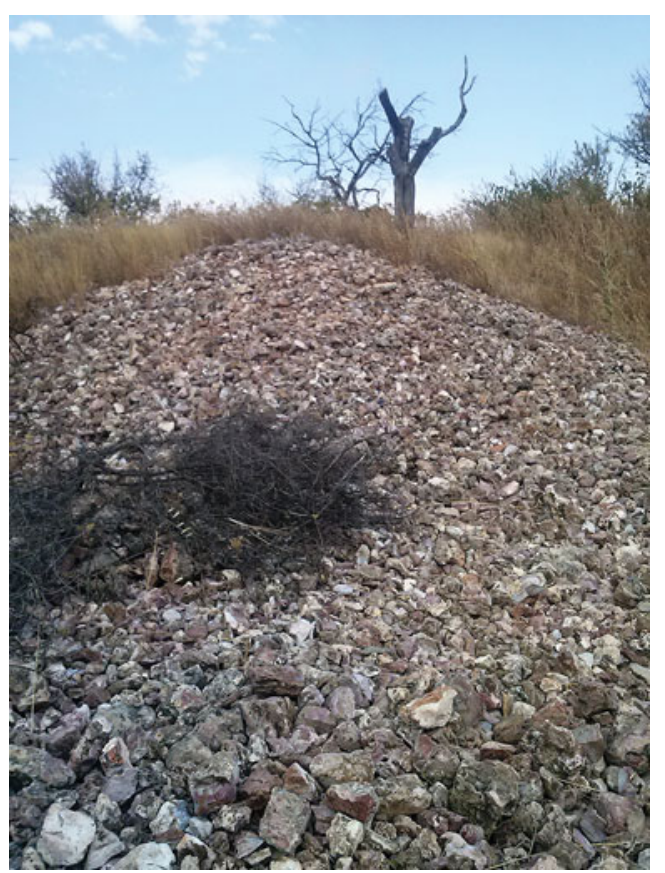

Figure 1. Flint-quarrying waste at the Les Pedrenyeres site (Ulldemolins). Iberia (LITOcat Project), and focused on archaeological research (Ortega \& Terradas 2014). During fieldwork, many indicators concerning the prehistoric procurement of flint have been evidenced (Figures 3-4). To analyse this evidence, we have launched a research project aimed at studying quarries and specific sites where the first transformation of siliceous raw materials took place. Our objective is to characterise the nature of flint procurement and the strategies used in flint extraction, and to attempt to determine the chronology and diachronic variability of the first stages in raw material exploitation. This goal is particularly relevant as siliceous rocks are relatively scarce in this area.

Archaeological surveying and recording have so far been carried out in four case studies (Figure 5), although excavations have only been undertaken at Montvell (Castelló de Farfanya). Here, nodular flint was quarried from lacustrine Oligocene limestones belonging to the Castelltallat Formation, an outcropping in the Serra Llarga hills. This provides the first example of a prehistoric site specialising in flint quarrying in north-eastern Iberia. Quarry faces were opened in the hill slopes, where the beds of rock outcrop vertically and are quite accessible, thereby allowing the opening of successive, stepped quarry fronts (Figure 6). Continuing chrono-stratigraphic study suggests a Neolithic chronology for this quarrying (Terradas et al. 2017), although the flint from the Castelltallat Formation was largely exploited during prehistory within a regional framework. In order to establish the distribution area of products knapped on this flint more precisely,

(C) Antiquity Publications Ltd, 2017 


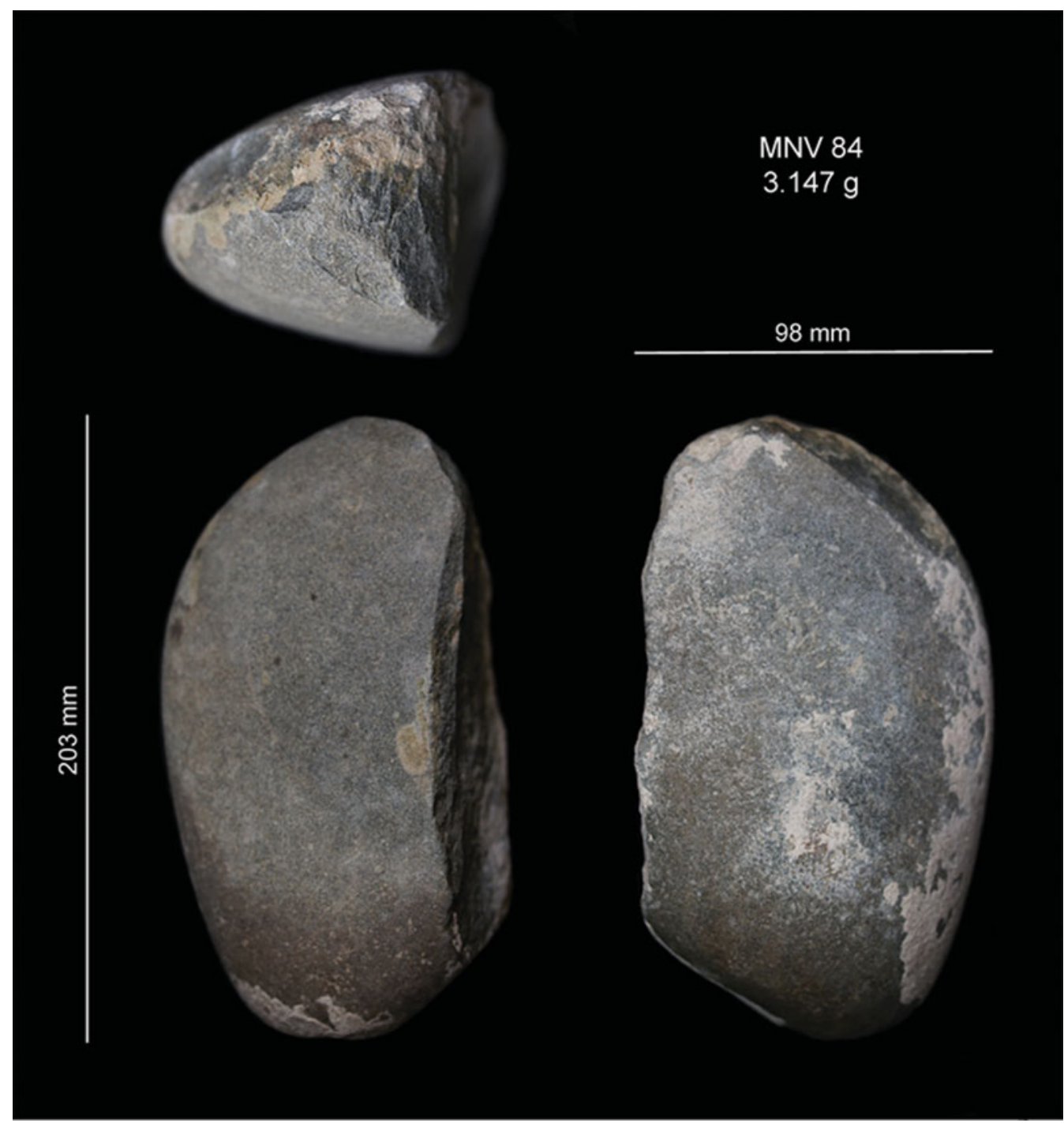

Figure 2. Hornfels hammer recovered from the surface of the Montvell quarries (Castello de Farfanya).

full petrographic, mineralogical and geochemical characterisation of the flint has been carried out (Ortega et al. 2017).

The research now in progress is focused on the application of remote-sensing techniques to locate a larger number of quarries. By using high-resolution LiDAR data and GIS tools, we hope to generate a more accurate image of the present surface where topographical irregularities generated by extractive activities might be identified. In our opinion, the arrangement of several stepped quarry fronts on the Serra Llarga hill slopes might be found elsewhere in the same layout, employed as a way to extract the raw material efficiently over

(C) Antiquity Publications Ltd, 2017 


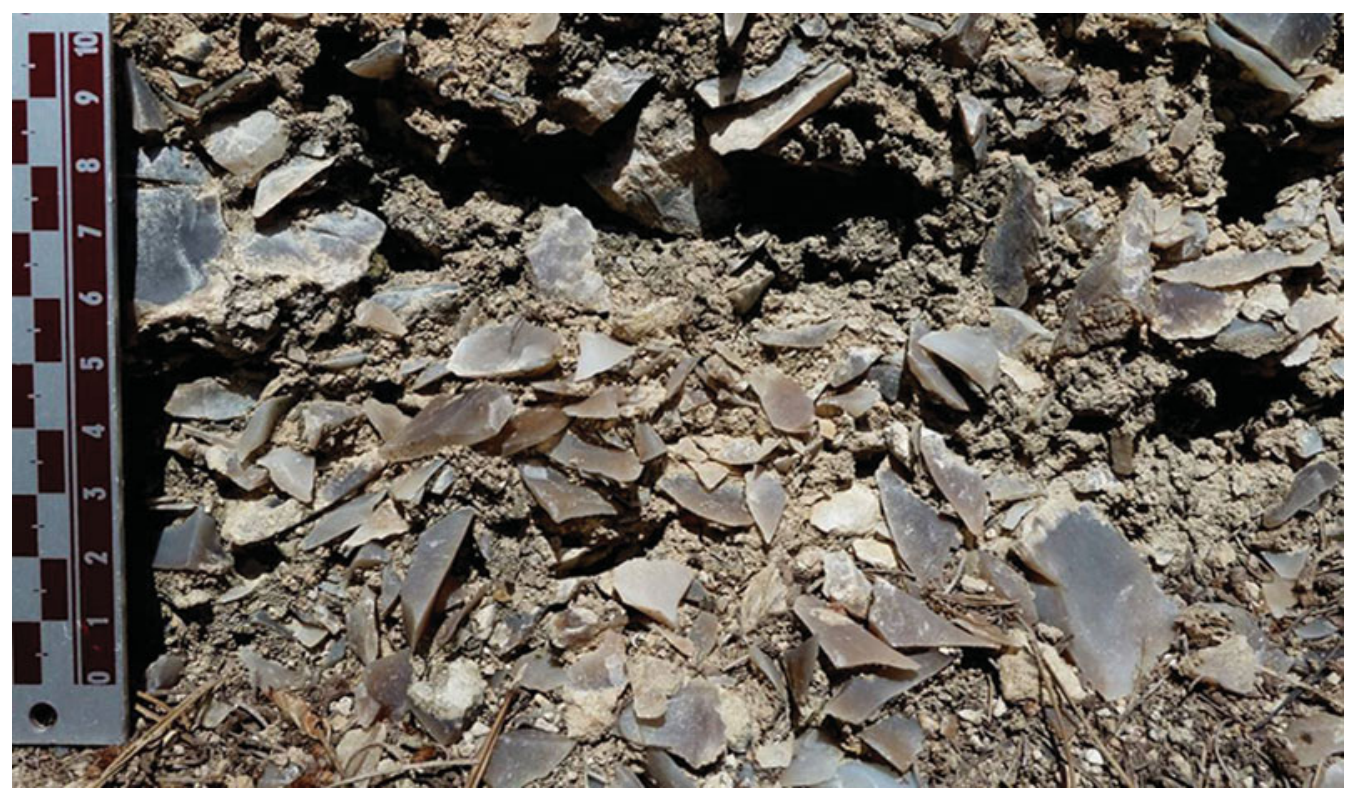

Figure 3. Accumulation of flint debris at the Cantacorbs site (Montblanc).

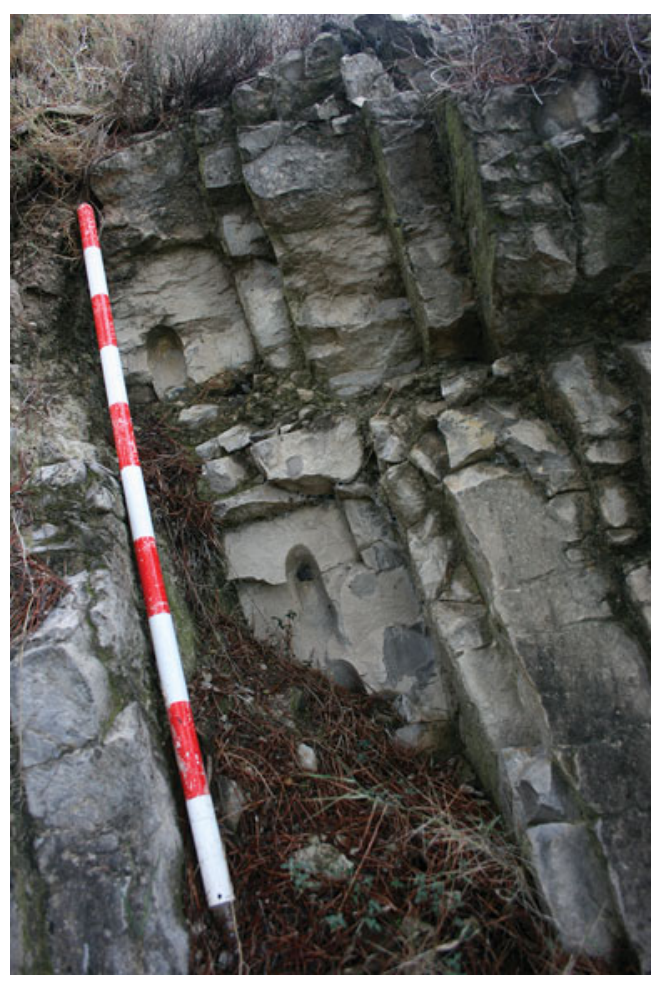

Figure 4. One of the Montvell quarry fronts (Castello de Farfanya) from which flint nodules have been extracted. extended periods of time. No evidence of the initial processing of raw material has yet been found among waste associated with quarries. The raw nodules may, therefore, have been carried to nearby places and settlements, where they would be knapped.

Although the project is still in its infancy, we hope that the excavation and study of all these sites will contribute significant information concerning the quarrying and initial transformation of flint. Furthermore, we hope to illuminate the relationship between quarries and neighbouring settlements in terms of the strategies implemented in the knapping, use and distribution of this type of flint. To this end, in the near future we will study some sites within the regional framework and look over the lithic assemblages from more distant sites. This way we hope to find further evidence for the exploitation of the flint from the Castelltallat Formation and to be able

(C) Antiquity Publications Ltd, 2017 


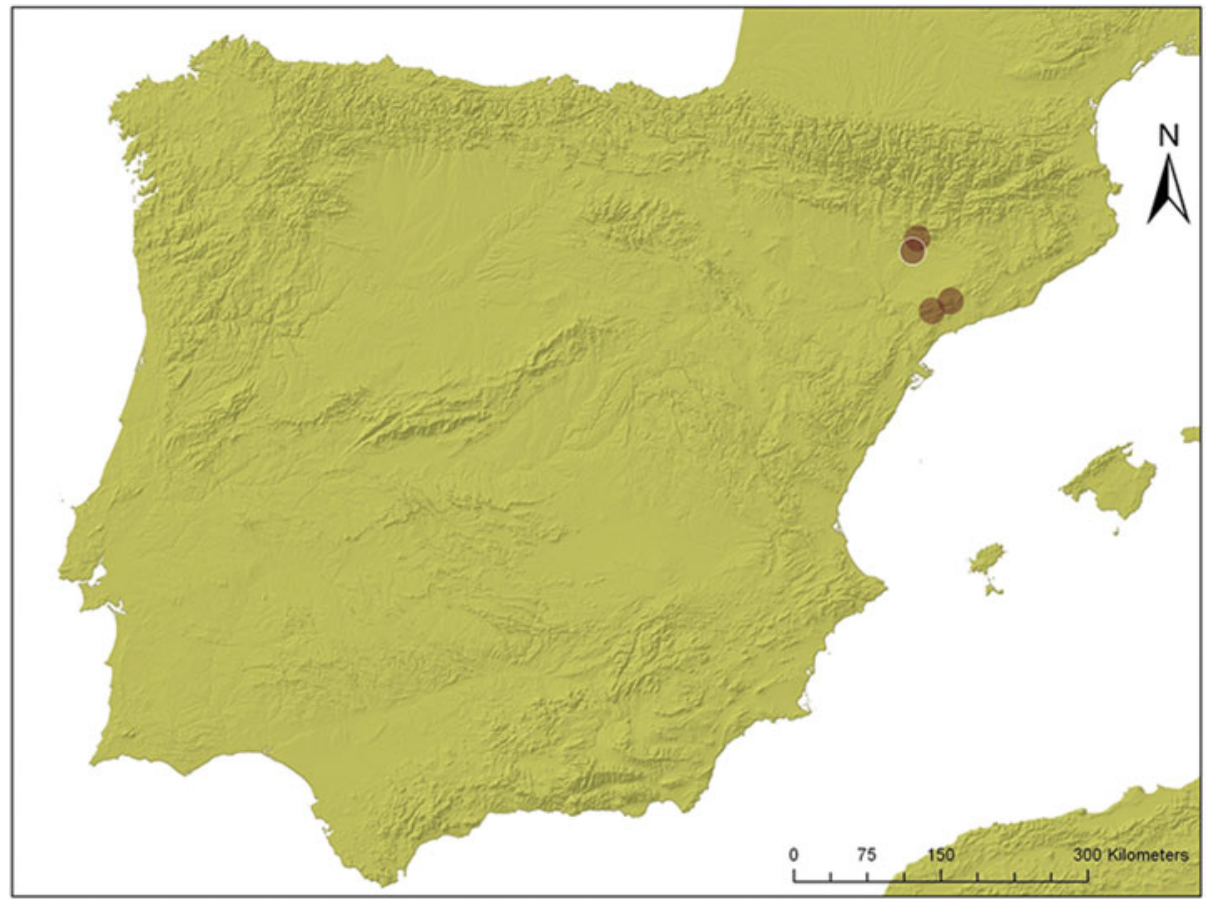

氕

Figure 5. Location of the four case studies in north-eastern Iberia. The circle with a white line corresponds to the Montvell quarries.

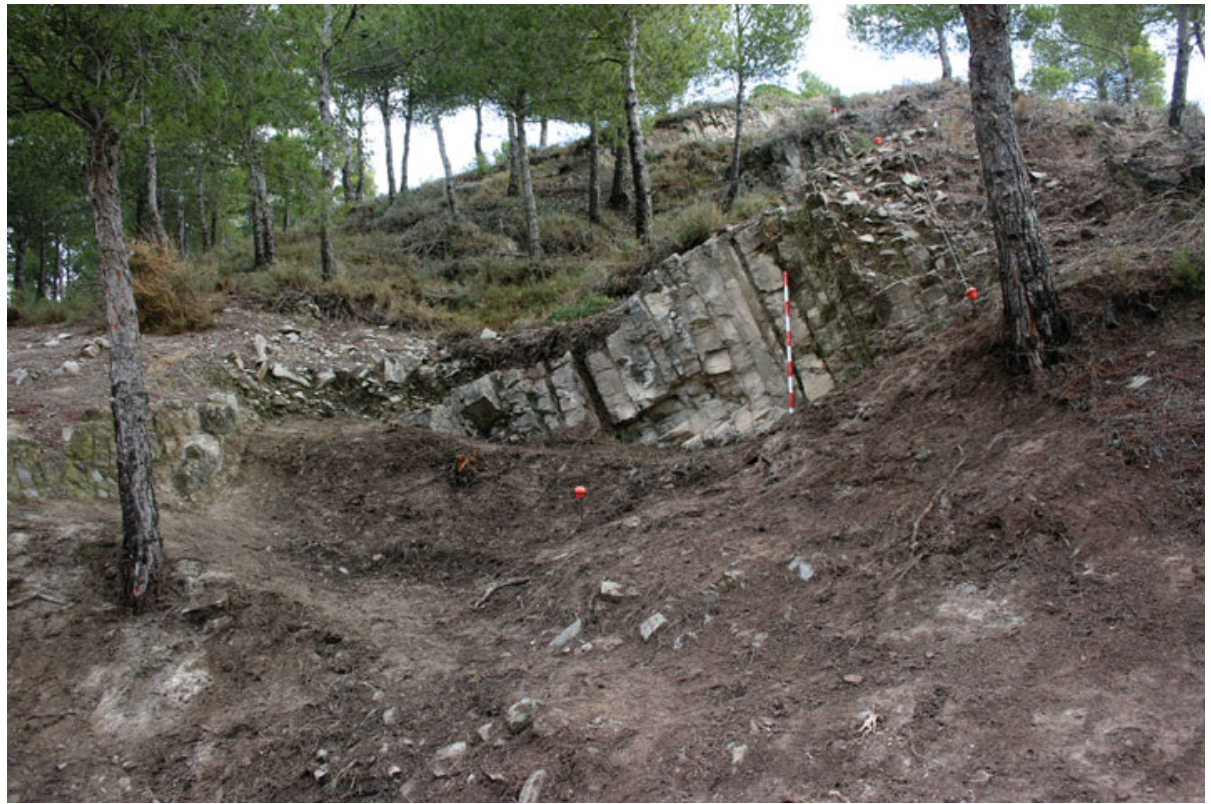

Figure 6. Three stepped quarry fronts opened on a hill slope in Montvell (Castelló de Farfanya).

(C) Antiquity Publications Ltd, 2017 
to identify more accurately the scope of its distribution in a wider geographic framework.

\section{Acknowledgements}

Archaeological surveying was funded by the Government of Catalonia and the Spanish National Research Council within the framework of the LITOcat Project. Excavation and research are sponsored by the Government of Catalonia ('Prehistoric and historic uses of flint in Catalonia: contexts of extraction and first transformation', grant 2014/100778) and the Spanish Ministry of Economy and Competitiveness ('Productions, technical variability and technological innovation in the Neolithic', grant HAR2016-76534C2-2-R).

\section{References}

Binder, D. \& C. PerLès. 1990. Stratégies de gestion des outillages lithiques au Néolithique. Paléo 2: 257-83. https://doi.org/10.3406/pal.1990.1004

ERICson, J.E. \& B.A. Purdy. 1984. Prehistoric quarries and lithic production. Cambridge: Cambridge University Press. https://doi.org/10.1017/CBO9780511753244

INGOLD, T. 2012. Toward an ecology of materials. Annual Review of Anthropology 41: 427-42. https://doi.org/10.1146/annurev-anthro-081309145920

Nelson, M. 1991. The study of technological organization. Archaeological Method and Theory 3: 57-100. Available at: http://www.jstor.org/stable/20170213 (accessed 18 July 2017).

Ortega, D. \& X. Terradas. 2014. The lithotheca of siliceous rocks from Catalonia, in F. Bostyn \& F. Giligny (ed.) Lithic raw material resources and procurement in pre- and protohistoric times (British Archaeological Reports international series 2656): 17-24. Oxford: Archaeopress.

(C) Antiquity Publications Ltd, 2017
Ortega, D., C. Roqué, J. Ibáñez, E. Beamud, J.C. Larrasoaña, A. Sáez \& X. Terradas. 2017. The chert from the Castelltallat formation (south-central Pyrenees): archaeometric characterization for archaeological research. Archaeological and Anthropological Sciences. First published online 7 January 2017. https://doi.org/10.1007/s12520-016-0458-1

Terradas, X. 2001. La gestión de los recursos minerales en las sociedades cazadoras-recolectoras. Madrid: CSIC.

Terradas, X., D. Ortega, D. Marín, A. Masclans \& C. RoquÉ. 2017. Neolithic flint quarries on Montvell (Catalan pre-Pyrenees, NE Iberia), in T. Pereira, X. Terradas \& N. Bicho (ed.) Raw materials exploitation in prehistory: sourcing, processing and distribution: 78-90. Newcastle upon Tyne: Cambridge Scholars. 